\title{
Питання психології
}

УДК: $159.9:[351.741: 343.102]$

DOI: $10.33099 / 2617-6858-2019-51-1-160-166$

Чухрасва Г. кандидат медичних наук, начальник, Центру психіатричної допомоги та професійного психофізіологічного відбору Держсавна установа «Територіальне медичне об’єднання Міністерства внутрішніх справ України в Харківській області»

\section{ВТІЛЕННЯ ПСИХОЛОГІЧНИХ ОСОБЛИВОСТЕЙ ПРАЦІВНИКА ОПЕРАТИВНО- РОЗШУКОВОЇ ДІЯЛЬНОСТІ В ПРАВОВУ СВІДОМІСТЬ}

Стаття присвячена визначенню основних психологічних особливостей особистості праиівника полічії всіх підрозділів поліиії, $і$ особливо, виокремити ичі аспекти у прачівників з оперативно-розиуковою діяльністю. На основі проведених емпіричних досліджень встановлено, щзо оперативно-розиукова діяльність пов'язана з високою правовою відповідальністю і свідомістю, які межують з високим ризиком водночас.

Ключові слова: правова свідомість; ризик; психологічні особливості; особистість; поліиія.

Постановка проблеми заключається в тому, що питання професійної свідомості та питання професійного ризику не мали можливості практично визначити ці поняття.

Аналіз останніх досліджень і публікацій. Більшість дослідників сходяться на тому, що в прояві професійної правосвідомості працівників поліщії особливе місце займають психологічні чинники. Проблема професійної правової свідомості працівників Національної поліщії України розкривається в дослідженнях В.Л. Васильєва та інших [4].

За даними I. В. Ващенко, коли дії в ситуації ризику працівника поліції спричинюють неочікуваний результат, а негативні наслідки у вирішенні проблем, в певної особистості виникають «особистісні особливості, що визначають схильність до переживання почуття провини» [5].

За К. К. Платоновим «особистість - це людина як носій свідомості» [8; 9].

Н. В. Гришина у своїх працях, пов'язаних 3 дослідженням проблеми особистості, зазначає, що психологічне вивчення особистості взаємопов'язане 3 дослідженням творчих моментів людської діяльності, розуміння яких дасть змогу надати психологічну характеристику й визначення особистості [6].

Мета статті: Метою даного дослідження $є$ визначення основних психологічних особливостей особистості поліщейського 3 оперативно-розшуковою діяльністю, які формують високу правову свідомість, не звертаючи увагу на часті ситуації, як пов'язані з ризиком.

Методи дослідження: Працівникам поліщії, особливо працівникам з оперативнорозшуковою діяльністю, були проведені психодіагностичні обстеження за методиками МБДО, а також емпіричні дослідження, такі як співбесіда, методи нагляду.

Перебуваючи в центрі соціальнополітичних процесів, працівники Національної поліції України в силу специфіки свого соціального положення покликані захищати як права і інтереси громадян відповідно до закону, так і інтереси держави, надавати соціальну допомогу різним категоріям населення. Психологічний аналіз діяльності працівників 3 оперативно-розшуковими функціями діяльності дозволяє зробити висновок про іiі складність, багатовимірність, інтенсивний i експресивний характер. Знання загальних закономірностей діяльності як соціальнопрофесійного феномену сприяє розумінню процесів іiі здійснення та підвищення ефективності.

Специфіка професійного становлення працівників Національної поліщії України, яка полягає в тому, що важливим $є$ їх розвиток не тільки як професіоналів, що володіють професійно важливими особистісними властивостями, але $\mathrm{i}$ як особистостей 3 особливими морально-вольовими, громадянськими якостями, готовністю до правоохоронної діяльності, сформованої професійної правової культурою і правосвідомістю, новоугворенням якого $\epsilon$ професійна правова свідомість [9].

Проблема професійної правової свідомості працівників Національної поліції України розкривається в дослідженнях В.Л. Васильєва та інших [4].

Більшість дослідників сходяться на тому, що в прояві професійної правосвідомості працівників поліції особливе місце займають психологічні чинники. Правова ідеологія по 


\section{Питання психології}

відношенню до психологічної складової правової свідомості не завжди відіграє основну роль. Правова свідомість працівника поліції представлена системою почугтів, установок, поглядів, ціннісних орієнтацій, уявлень та іiі інших складових.

Вивченням правосвідомості працівника поліції займається правова психологія, а саме: вивчає закономірності розвитку i функціонування правосвідомості та правослухняної поведінки людини, змін цієї поведінки у зв'язку з соціально-економічними реформуваннями в структурі суспільства [7].

Сформованість професійної правової свідомості $\epsilon$ основним чинником серед чинників свідомості працівника 3 оперативнорозшуковими функціями діяльності. Служба в поліції є однією з самих складних в силу різних причин, тим паче, вона залишається низько оплачуваною i на сьогоднішній день. Цей чинник $є$ негативним в першу чергу тим, що не дозволяє залучити на службу високоінтелектуальну та перспективну частину молоді, яка намагається знайти себе на інших ділянках діяльності. Тим не менше професія потребує від людини великої віддачі, так як відрізняється непомірно великою фізичною, емоційною, моральною напругою, ненормованим робочим днем, ризиком для життя та здоров'я [3].

Службова діяльність осіб рядового та начальницького складу пов'язана 3 підвищеною відповідальністю працівників за свої дії. Під час виконання службового обов'язку працівникам нерідко доводиться знаходитися в ситуаціях з непередбачуваним результатом, які характеризуються недостатньою визначеністю рольових функцій, психічними і фізичними перевантаженнями, необхідністю спілкуватися 3 найрізноманітнішим контингентом громадян $\mathrm{i}$ вимагає від працівника рішучих дій і здатності піти на ризик.

Найчастіше працівників поліції провадиться в напружених умовах, конфліктних ситуаціях, небезпечних для життя обставинах.

Якщо працівник спецпідрозділу поліції володіє емоційно-вольовою

стійкістю, він легше долає психологічні наслідки невдач і зривів [1].

Зрозуміло, що більше позитивних («ділових») якостей має людина, то швидше вона буде досягати будь-яких цілей. Тому розвиток цих якостей повинен бути пріоритетним у розвитку особистості працівника поліції.

Особистість - це системна якість, яку здобуває суб'єкт (індивід) у системі діяльностей, що здійснюють його життя в суспільстві й у системі об’єктивних відносин суспільства [2].

За К. К. Платоновим «особистість - це людина як носій свідомості» [8;9].

Н. В. Гришина у своїх працях, пов'язаних 3 дослідженням проблеми особистості, зазначає, що психологічне вивчення особистості взаємопов'язане 3 дослідженням творчих моментів людської діяльності, розуміння яких дасть змогу надати психологічну характеристику й визначення особистості [6].

Відповідно до «Закону про Національну поліцію України» ст. 29 «Основні принципи служби в Національній поліції України» одними 3 основних принципів працівника поліції $\epsilon$ професіоналізм, компетентність, ініціативність відданість справі, а також особиста відповідальність за свої власні дії і за незаконність або бездіяльність.

Тому в екстремальних ситуаціях, коли обмаль часу для прийняття рішень та дій рівень професіоналізму, компетентності є запорукою позитивного результату в випадках ризику.

Ризик - це поняття, яке залежить від емоційної стійкості, від особистісних особливостей особистості, від його інтелектуальних здібностей та деяких інших. Динамічні особливості психічної діяльності залежать від емоції і від волі. Тому вони визначаються відношенням емоційних i вольових особливостей. Ризик може бути i необхідним, і невиправданим [8].

Розумна схильність до ризику - це швидкість реакції, вміння орієнтуватися в складній обстановці.

Ризик - ситуативна характеристика діяльності, що полягає в невизначеності іiі результату i можливих несприятливих наслідках в разі неуспіху [9].

Ризик характеризується можливістю вибору між менш або більш небезпечними для працівника поліції варіантами поводження, але розрізняються за ступенем їхньої ефективності 3 погляду досягнення результатів діяльності.

Часто ризиковане поводження дає змогу досягти мети діяльності швидше й 3 мінімальними втратами. Самі види ризику різноманітні: ризик зриву рішення службового завдання, ризик одержання стягнення, ризик 


\section{Питання психології}

звільнення 3 посади, ризик одержання фізичного ушкодження, ризик для свого життя, ризик для свого авторитету й морального престижу й ін. [9].

За даними I. В. Ващенко, коли дії в ситуації ризику працівника поліції спричинюють неочікуваний результат, а негативні наслідки у вирішенні проблем, в певної особистості виникають «особистісні особливості, що визначають схильність до переживання почугтя провини» [5].

Спірним було питання, чи дасть змогу методика виявити особистісні властивості індивіда або особливості його стану. Сьогодні більшість дослідників уважає, що особливості стану значною мірою визначаються індивідуальним типом реагування й виявляються посиленням, загостренням або ослабленням особистісних якостей [10].

У сучасних умовах від працівників поліції вимагається: посилення професійного потенціалу, забезпечення психологічної готовності до екстремальних ситуацій та уміння своєчасно реагувати на ситуацію, захищаючи правопорядок. $\mathrm{y}$ період проведення реформування, яке торкається всієї системи правопорядку МВC психологічне навантаження на працівників системи ще більше зростає.

3 огляду на професійну діяльність працівників 3 оперативно-розшуковими функціями, їх служба є найбільш небезпечною та складною. Ці працівники повинні мати високу мотивацію досягнень, впевненість у собі, позитивну самооцінку, зокрема рішучість, яка близька схильності до ризику, а значить i високу ступінь адаптації.

Функція адаптації визначається переважно двома чинниками, а саме: прагненням особистості до самореалізації, до досягнення мети й задоволення потреб у протидії Діючим чинникам середовища, що обмежують самореалізацію особистості, а також тенденцію до підвищеного самоконтролю 3 відмовою від досягнення потреб заради збереження конкрентних відносин 3 оточенням. Перевага показників стенічної самореалізації може спричинювати порушення адаптації за соціальноповедінковим типом насамперед, гіпостенічний стан означає відмову від самореалізації й перевагу соціального тиску i тиску середовища на особистість, що сприяє виникненню невротичного патерну дезадаптації. В разі перенапруження тих й інших тенденцій відбувається взаємне їхнє зниження. Блокованими виявляються невротичний і поведінковий відвідні канали, які відреагували в емоційному регістрі, що приводить до дезадаптації.

Працівникам поліції, особливо працівникам 3 оперативно-розшуковою діяльністю, були проведені психодіагностичні обстеження за методиками МБДО, а також емпіричні дослідження, такі як співбесіда, методи нагляду. Нами були отримані наступні результати 3 данними психологічних особливостей данних працівників поліції. Прагнення до лідерства, суперництва, домінування, подолання перешкод, самостійності в прийнятті рішень і дій. Високий рівень пошукової активності. Прагнення до незалежності, вільної поведінки, безпосередності. В умовах емоційного залучення - чітко виражені протилежні емоції. Мотив досягнення успіху пов'язаний $з$ волею до реалізації сильних бажань; схильність до ризику. Висловлення й дії не можугь випереджати планомірну і послідовну продуманість учинків. Можна 3 впевненістю зазначити, що така риса характеру, як схильність до ризику, особливо притаманна працівникам поліції спеціальних оперативних підрозділів. Для працівників пспеціальних підрозділів поліщії більш характерні: схильність до ризику, здатність і схильність до високої активності, невимушеності в спілкуванні, ініціативності, ризику. Прагнення буги в центрі уваги, максимально інформованим. Енергійність, висока працездатність, витривалість, організаційні здатності. їхнє лідерство зазвичай сприймається оточуючими як природне явище. Добре розвинені навички спілкування.

Особи рядового та начальницького складу підрозділу БПОП (колишнього СПШР) - більш рішучі, життерадісні, владні, мають егоїстичний тип особистості, у них переважають: соціальна пристосованість, широке коло інтересів, сценічність, багата уява, наполегливість, упертість, виражене прагнення до емоційного залучення, сензи- тивність до критичних зауважень i зовнішніх впливів, схильність до перебільшення своїх можливостей, невимушеність у спілкуванні, здатність висловлювати свою думку, готовність поділитися враженнями.

Ці специфічні особливості професійної діяльності роблять значний вплив на особистісні характеристики іï представників і 


\section{Питання психології}

можуть призводити до негативних соціальнопсихологічних наслідків [11].

Оперативно-службові завдання, що стоять, наприклад, перед працівниками кримінальних та слідчих підрозділів, вимагають прояву специфічних професійних якостей, найважливішими 3 яких є здатність до адекватної самооцінки. У працівників поліції, представників цих двох професійних груп, мають бути сформовані деякі соціальнопрофесійні якості, що дозволяють їм успішно виконувати складні завдання, взаємодіяти 3 іншими людьми. У такому розумінні соціально-професійні групи - це сукупність фахівців, професійна діяльність яких пов'язана iз спілкуванням i взаємодією 3 людьми. Специфічність соціально-професійних груп працівників Національної поліції України являє собою особистісні якості, які проявляються в адекватності рішення (стандартних та які вимагають творчого підходу). Професійна ідентифікація особистості працівника Національної поліції України залежить, в першу чергу, від професійної самосвідомості як системи особистісних якостей, які демонструються в професійній діяльності всьому суспільству. Відповідність професійної ролі і особливостей особистості працівників $\epsilon$ структурнофункціональною відповідністю, на підставі якої функціонує професійно-особистісна модель працівника в громадській думці. Деформація структурно-функціональної відповідності професійної ролі працівників Національної поліції України і їх особистісних проявів викликає суспільну потребу в корекції відповідності ролі і поведінки службовця [4].

Так, у процесі вирішення оперативнорозшукових завдань оперуповноважений працівник та слідчий часто змушений впливати специфічно та психологічно на різні категорії громадян, зокрема, для отримання оперативної інформації в процесі спілкування 3 конфіденційними джерелами, в ході опитувань i допитів, що висуває дуже високі i різносторонні вимоги до особистості працівника, а наявність знань і вмінь у сфері комунікативної взаємодії та вирішення конфліктних ситуацій при здійсненні профілактичних завдань відіграють величезну роль. Вивчення особистісних особливостей працівників Національної поліції України представників різних соціально-професійних груп залежно від соціально-демографічних i професійних характеристик $€$ головною складовою для реалізації психологічного потенціалу особистості працівників i соціально-психологічного супроводу їх діяльності, особливо для працівників Національної поліції України 3 оперативнорозшуковими функціями діяльності[12].

Якщо усвідомлення особистістю свого зв'язку з групою своєї спільноти відіграє роль спонукання і емоційно забарвлене, то загальні елементи у змісті свідомості членів групи значною мірою регулюють їх спільну діяльність. Отже, якщо на рівні самооцінок не забезпечується єдиної подібності, цілісності, то не виникає передумов для формування професійної групової свідомості. Залежність станів групової свідомості від рівня розвитку групи безсумнівна[9].

У разі великої кількості міжособистісних контактів у різних сферах, $\epsilon$ імовірність нетривалого, поверхневого спілкування. Здатність переносити неминучі труднощі в спілкуванні без реакцій тривоги і пригніченості. Виражені схильність до пригод, хоробрість, наполегливість, упертість, заповзятливість, прагнення до подолання перешкод, самоствердження; постійне прагнення до зовнішньої збудливої ситуації. Властива демонстрація мужнього стилю життя, сили, витривалості, зневаги до дріб'язків, наполегливості. $\mathrm{C}$ значущим соціальний престиж. Не виключена підвищена чутливість стосовно дійсних або уявних несправедливоетей. Характерні життєрадісність, рішучість, упевненість у собі, владність, екстравертованість, честолюбство. Прагнення керуватися твердим наміром буги кращим, розумнішим від інших, лідирувати в груповій діяльності. Для задоволення честолюбства необхідні реальні досягнення й результати, що підтверджують престиж i значущість.

У широкому плані поняттям професійної свідомості можна визначити всі ті прояви свідомості особистості, які пов'язані 3 ii професійною діяльністю. Вони визначаються: місцем i значенням даної професії в професійній структурі суспільства; ставленням особистості до професії, іï представникам і до себе як професіонала; професійними ідеалами. Більшість авторів вкладають в це поняття усвідомлення людиною своєї приналежності до певної професійної групи та трактують його як вибіркову діяльність самосвідомості особистості, підпорядковану завданню самовизначення; усвідомлення себе як суб’єкта 


\section{Питання психології}

професійної діяльності. У цьому випадку стають очевидними дві головні особливості суб'єкта даної діяльності. По-перше, він набуває рис полісуб'єктності, знаходить статус колективного (групового) суб'єкта. По-друге, суб'єкт стає при цьому не тільки «множинним» i «розподіленим», але i організованим. Завдяки рефлексивним властивостям і процесам відбувається не тільки диференціація - виділення індивідуального суб'єкта («Я сам»), а й стає можливою їх подальша інтеграція в рамках колективного суб’єкта («Ми разом») [13].

Ми розуміємо під груповою професійною свідомістю працівника поліції усвідомлення себе в системі своєї професійної діяльності, в системі професійного спілкування та взаємодії з населенням, в системі власної особистості.

Висновки.

Захист інтересів держави та інтересів громадян, які виконують працівники поліції, особливо працівники 3 оперативнорозшуковою діяльністю, пов'язаний з високою правовою свідомістю і відповідальністю, які в першу чергу формуються на основі основних психологічних особливостей особистості поліщейського. При проведенних психологічних обстеженнях працівникам поліції спеціальних підрозділів і працівників 3 оперативно-розшуковою діяльністю можно зазначити, що такимми спільними рисами $\epsilon$ Прагнення до лідерства, суперництва, домінування, подолання перешкод, самостійності в прийнятті рішень і дій.
Високий рівень пошукової активності. прагнення до незалежності, вільної поведінки, безпосередності. В умовах емоційного залучення - чітко виражені протилежні емоції. Мотив досягнення успіху пов'язаний 3 волею до реалізації сильних бажань; схильність до ризику. Висловлення й дії не можугь випереджати планомірну і послідовну продуманість учинків. Можна 3 впевненістю зазначити, що така риса характеру, як схильність до ризику, особливо притаманна працівникам поліції спеціальних оперативних підрозділів. Для працівників пспеціальних підрозділів поліції більш характерні: схильність до ризику, здатність і схильність до високої активності, невимушеності в спілкуванні, ініціативності, ризику. Прагнення буги в центрі уваги, максимально інформованим. Енергійність, висока працездатність, витривалість, організаційні здатності. ӥхне лідерство зазвичай сприймається оточуючими як природне явище. Добре розвинені навички спілкування.

Оперативно-службові завдання, що стоять, наприклад, перед працівниками кримінальних та слідчих підрозділів, вимагають прояву специфічних професійних якостей, найважливішими з яких є здатність до адекватної самооцінки. У працівників поліції, представників цих двох професійних груп, мають бути сформовані деякі соціальнопрофесійні якості, що дозволяють їм успішно виконувати складні завдання, взаємодіяти 3 іншими людьми.

\section{Список використаних джерел}

1. Бандурка А. М. Профессионализм и лидерство : учеб. пособ. / А. М. Бандурка, С. П. Бочарова, Е. В. Землянская. - Харьков : Титул, 2006. - 578 с.

2. Барко В. И. Профессиографическое описание основных видов деятельности в ОВД Украины. К.: КНУВД, ГП. Типография МВД, 2007.

3. Берестовой С.Г. Социально-психологические представления о качестве жизни в профессиональном пространстве ОВД. 19.00.05 - Авторефер. дис. канд. псих. наук, Кострома - 2006.

4. Васильев В.Л. Системный профессиографический подход к подбору и расстановке кадров правоохранительных органов // Материалы междунар. научн. практ. конф. СПб., 1995. - С. 65-70

5. Ващенко I.В. jarina 62@ ravifer. ru . Проблеми сучасної психологіï. 2016. Випуск 34.

6. Гришина Н.В. Психологія конфлікту. - 2-е вид., - СПб.: Пітер, 2008.

7. Мерищук Л.В. Психологические основы формирования профессионально значимых качеств; Дис. Дра психол. Наук / В.Л. Мерищук. Л., 1982.-351 с.

8. Платонов К.К. Необходимые уточнения (о методических проблемах профессионального отбора в профессиональной ориентации) // Социалистический труд, N 10, 1970, С. 94 - 100.

9. Платонов К.К. Система психологии и теория отражения /К.К. Платонов.-М.: Наука, 1982. - 310с.

10.Слєдков Е.В. Боєва психічна травма (клініко-патогенетична динаміка, діагностика, лікувальнореабілітаційні принципи): Автореферат докт. мед. наук. -СПб.: 1997. - 48 с.

11.Чухраєва Г.В. Психологічні особливості схильності до розвитку професійної деформації особистості / Г.В. Чухраєва // Науковий Вісник Миколаївського Національного університету ім.. В.О. Сухомлинського. 2014. -№2.12 (103) - С. 235-238. 


\section{Питання психології}

12.Чухраєва Г.В. Соціально-психологічні особливості якості життя працівників ОВС / Г.В. Чухраєва // Вісник Національного університету оборони України. Харків - 2014. -№2 - С. 313-318.

13.Шестов Л. Киркегард и экзистенциальная философия. М., 1992.

\section{References}

1. Bandurka A.M. Professionalism i liderstvo: echebn. posob. / A.M. Bandurka, S. P. Bocharova, E.V.Zemlianskaia. - Kharkiv: Title, 2006. - 578 s.

2. Barko. V.I. Professiograficheskoe opisanie osnovnykh vidov deiatelnosti v OVD Ukraine. K.: KNUVD, Tipografiia MVD, 2007.

3. Berestovoi S.G. Socialno-psychologicheskie predstavleniia o kachestve zhizni v professionalnom prostranstve OVD. 19.00.05 - Avtorefer. dis. kand. psikh. nauk, Kostroma - 2006.

4. Vasilev V.L. Sistemnyy professiograficheskiy podkhod $\mathrm{k}$ podboru $\mathrm{I}$ rasstanovke kadrov pravookhranitelnykh organov // Materials mezhdunar.nauch. prakt. konf. SPB., 1995. - S. 65-70

5. Gryshyna N.V. Psykhologiia konfliktu. -2 is a e kind., - SPB.: Piter, 2008.

6. Meryshchuk L.V. Psychologicheskie osnovy formirovaniia professionalno znachimykh kachestv; diss. Dokt. Psikhol. nauk / Meryshchuk V.L., 1982.-351 s.

7. Plato of K.K. Necessary clarifications (about the methodical problems of professional selection in a professional orientation) // are Socialistic labour, N 10, 1970, S. 94 - 100.

8. Platonov K.K. Neobkhodimye utochneniia (o metodicheskikh problemakh professionalnogo otbora $\mathrm{v}$ professionalnoi orientatsiyi/K.K. Platonov - M.: Nauk, 1982.-310 s.

9. Sliedkov E.V. Boieva travma (Kliniko-patogenetychna dunamika, diagnostyka, Likuvalno-reabilitatsiini pryntsypy): Avtoreferat dokt. med. Nauk. - SPB.: 1997. - 48 s.

10. Chukhraeva G.V. Psychologichni osoblivosti skhylnosti do rozvytku professiinoi deformazii osobustosti / G.V. Chukhraeva // Naukovyi Visnyk Mykolaivskoho Nationalnoho universitetu im. V.O. Sukhomlinskogo - 2014. №2.12 (103) - S. 235-238.

11. Chukhraeva G.V. Sozialno-psychologichni osoblivosti yakosti zhuttya prazivnykiv OVS / G.V. Chukhraeva // Visnyk Nazionalnogo universitetu oborony Ukrayiny. Kharkiv - 2014. -№2 - S. 313-318.

12. Shestov L. Kirkergard I ekzistentsialnaya filosofiya. M., 1992.

\section{Резюме}

Чухраева А. кандидат медииинских наук, начальник, Центр психиатрической помощи и профессионального психофизиологического отбора Государственное учрељждение «Территориальное медиинское управление Министерства внутренних дел Украины в Харьковской области»

ВНЕДРЕНИЕ ПСИХОЛОГИЧЕСКИХ ОСОБЕННОСТЕЙ СОТРУ ДНИКОВ ОПЕРАТИВНОРОЗЫСКНОЙ ДЕЯТЕЛЬНОСТИ В ПРАВОВУЮ СОЗНАТЕЛЬНОСТЬ

Статья посвящена определению основных психологических особенностей сотрудника полици всех подразделений полищии, а особенно, выделить эти аспекты у сотрудников с оперативно-розыскной деятельностью. На основании проведенных эмпирических исследований определено, что оперативнорозыскная деятельность связана с высокою правовою ответственностью и сознательностью, которые граничат с высоким риском одновременно.

Ключевые слова: правовая сознательность; риск; психологические особенности; личность; полиция.

\section{Summary \\ Chuhraeva G. candidate of medical sciences, Chief, Center of psychiatric help and professional psikhofiziologickal selection Public institution the «Territorial medical association of Ministry of internal affairs of Ukraine in the Kharkiv area»}

\section{EMBODIMENT OF PSYCHOLOGICAL FEATURES OF WORKER OF OPERATIONAL} SEARCH ACTIVITY IN LEGAL CONSCIOUSNESS

Introduction The article is sanctified to determination of basic psychological features of personality of worker of police of all subdivisions of police, and especially, to distinguish these aspects for workers with operational search activity. It is set on the basis of the conducted empiric researches, that operational search activity is related to high legal responsibility and consciousness, that abut upon a high risk at the same time.

Purpose Aim of this research is determination of basic psychological features of personality of policeman with operational search activity, that form high legal consciousness, not paying attention to frequent situations, as related to the risk. 


\section{Питання психології}

Methods To Workers of police, especially to the workers with operational search activity, psihodiagnostik inspections were conducted after methodologies of $M B D O$, and also empiric researches, such as interview, methods of supervision.

Originality a scientific novelty consists in that problem of professional consciousness and risk considered not only from scientific position, and in connection with the psychological features of workers of police, that it is possible to define by means of psihodiagnostikal inspection.

Conclusion. Defence of interests of the state and interests of citizens, that execute workers of police, especially workers with operational search activity, related to high legal consciousness and responsibility, that is first of all formed on the basis of basic psychological features of personality of policeman. At проведенних psychological inspections to the workers of police of the special subdivisions and workers with operational search activity of it is possible to mark that такимии general lines are Aspiring to leadership, rivalry, prevailing, overcoming of obstacles, independence in making decision and actions. High level of searching activity. aspiring is to independence, free behavior, spontaneity. In the conditions of the emotional bringing in - opposite emotions are clearly expressed. Reason of achievement of success is related to will to realization of strong desires; propensity is to the risk. An utterance and actions can not pass ahead systematic and successive carefully thought out of acts. It is possible with a confidence to mark that such character trait, as propensity to the risk, especially inherent to the workers of police of the special operative subdivisions. For the workers of spezial subdivisions of police more characteristic: propensity to the risk, capacity and inclination for high activity, to the ease in a commonunication, initiativeness, risk. Aspiration to be in highlight, maximally informed. Energeticness, high capacity, endurance, organizational capabilities. their leadership is usually perceived by surrounding as the natural phenomenon. Well — developed skills of commonunication.

Operatively-official tasks that stand for example, before the workers of criminal and inquisitional subdivisions, require the display of specific professional internalss major from that is a capacity for an adequate self-appraisal. For the workers of police, these representatives of two professional groups, some socialprofessional internalss, that allow to them successfully to execute difficult tasks, co-operate with other people, must be formed.

Key word: legal consciousness; risk; psychological features; personality; police. 